\title{
Stock Return Response to Monetary and Fiscal Policy Interaction in Singapore
}

\author{
Ghulam Ali \\ Department of Business Administration, University of Sarogdha, Pakistan \\ Email: ghulamali.bhatti@yahoo.com \\ Khalid Zaman \\ Department of Management Sciences, COMSATS Institute of Information Technology, Abottabad, Pakistan \\ Email: khalidzaman@ciit.net.pk \\ Sayed Mahdi Ziaei \\ Senior Lecturer, Faculty of Management, University Technology Malaysia (UTM), Malaysia \\ Melati Ahmad Anuar \\ Senior Lecturer, Faculty of Management, University Technology Malaysia (UTM), Malaysia
}

\section{Doi:10.5901/mjss.2014.v5n27p1712}

\section{Abstract}

The objective of the study is to examine the monetary and fiscal policies' shock on house price variable by using the structural vector autoregressive (SVAR) model for Singapore economy. In addition, the study used international oil prices and gold prices in the SVAR model because concurrent development in oil and gold prices have central influenced over macroeconomic activities that are closely linked with the stock returns. The results indicate that oil price has significant positive effect on gold prices, interest rates and stock returns. Exchange rate and government expenditure shows a negative impact on oil prices. The inverse relationship between gold prices, exchange rate and stock return supports that gold used as a hedge against both markets. However, there is no evidence has been found for crowding out effect through increase in government expenditures. Interaction between exchange rate and stock return is supportive to both stock-oriented and flow oriented models.

Keywords: Stock return; Fiscal policy; Monetary Policy.

\section{Introduction}

The economy of Singapore is considered as an economic and financial hub among South-East Asian countries. This economy mainly depends on international trade. Traditionally, the manufacturing and service sectors of this country is very strong and therefore, it has emerged with highest per capital gross domestic products (GDP) over the globe (Dfat, 2013). Over the years, Singapore encouraged financial institutions through multiple incentives and opportunities to establish their businesses (Credit-suisse, 2013).

Singapore is highly developed and free market economy with corruption free environment. During 2004-07, the country maintained its real GDP as $8.6 \%$ on average, but after global financial crises its economy starts contracting. House prices are showing an increasing trend after 2010 and government expenditure demonstrates consistent increase every year. Extra-ordinary decrease in short-term interest rate shows expansion in monetary policy. A rapid appreciation in exchange rate can be seen since global crisis of 2008 , whereas stock prices demonstrate varying but rising trend since 2008 crisis. Figure 1 shows the current financial trends in Singaporean economy. 

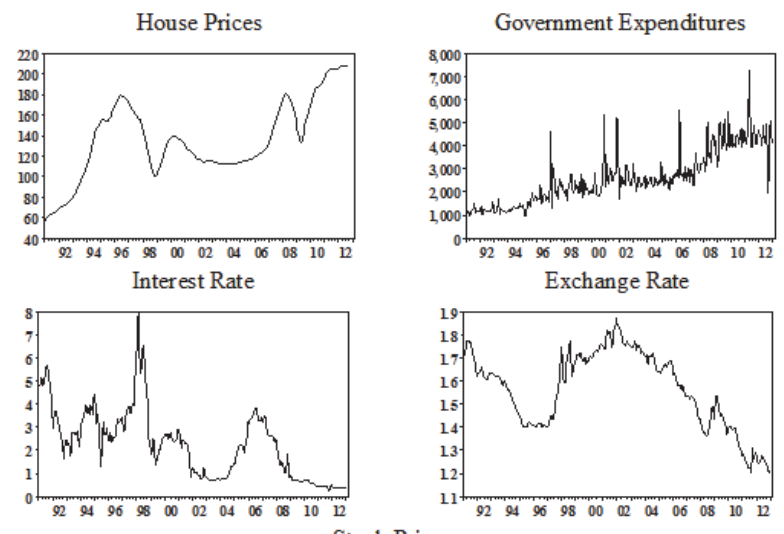

Stock Prices

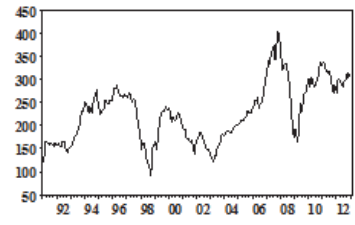

Figure 1: Current Financial Trends in Singapore

House prices in Singapore are skyrocketing and it is forecasted that this country is on the brink of property crisis. The reason of rapid growth in property prices is ease in loans because of lowest mortgage rate (i.e. 1 percent) as compared with other Asian countries such as Hong Kong, China and South Korea where mortgage rate is 2.15 percent, 7.43 percent and 5 percent respectively. Therefore, residential home become more attractive to households. According to News Asia Channel (2013) that household debt is increased from 64.4 percent to 77.2 percent of gross domestic product from early 2008 to early 2013. As regards to public debt, Singapore is listed in top eleven country having 111.40 percent public debt of gross domestic product (World Factbook, 2013).

Over the years, monetary policy is exchange-based and monetary authority of Singapore (MAS) has deep concern with their exchange rate. It is maintained and managed by MAS in consideration of trade competitors and partners' tradeweighted basket currencies Basket. Excessive fluctuations in exchange rate are prevented through government intervention. The main purpose is to stabilize the price level to achieve sustainable economic growth. MAS are not very much concerned with interest rate as compared to exchange rate. They believe that the economy is based on international trade, therefore, monetary system should be managed through stable exchange rate rather interest rate.

The government expenditures are focused by fiscal policy to provide goods and services. National security, health care and public housing is on the priority of Singaporean government. Over the last three decades, one-third of expenditures are spent on development. The primary focus of fiscal policy is to achieve long-term economic growth; therefore, government concentration is on private sector, considering it as the engine of growth (MAS, 2013).

Singapore main index is performing better than expected earnings but this situation is not free from headwinds (e.g., property bubble and squeeze in banking system). Inflation rate is 4 percent over the past two year due to surge in rent and car prices, whereas unemployment rate is increased from 1.8 percent to 1.9 percent during 2012-2013. Weak global economic picture is susceptible for Singapore as being an export-dependent economy. Performance of Singapore index is laggard as compared to China and Korea during this year. Property, financial and agricultural stocks are dominant in index but recent performance of these stocks is lacklustre (Holliday, 2013).

Considering above scenario, it is the need of time to conduct a study which consider the above matter of Singaporean economy. Current study is considering four blocks of variables: international block, property block, monetary block and fiscal block. Keeping in mind the above facts, six variables (oil and gold price from international block, house prices from property block, government expenditures from fiscal block and short-term interest rate \& exchange rate from monetary block) are selected to examine the impact of these variables on stock returns. Because stock market is forwardlooking market that captures the impact of all changes immediately comes through public policies or private sector (Bjørnland \& Leitemo, 2009). Through survey of literature does not disclose any study which captures this set of variables with stock returns in Singapore.

This study fills this void and this study will provide fresh information to policy makers, investors and financial 
specialists. As pointed by Dungey and Fry (2009) that each stock market is contemporaneously responsive to external and international shocks. The success of government policy makers depends on deep understanding of monetary and fiscal shocks in combination with stock markets. It is realised by academic circles that the impact of monetary and fiscal policies should be analysed in tandem rather in insolation because both policies have vital role in economic and financial activities of the economy and resulting in stock market performance (Chatziantoniou et al., 2013).

Thorough review of literature shows that a large number of recent studies examined the association of monetary policy and stock prices (Berg, 2012; Bhuiyan, 2012; Bjørnland \& Leitemo, 2009; Bouakez et al., 2013; Cassola \& Morana, 2004; Challe \& Giannitsarou, 2012; Galí \& Gertler, 2007; Patelis, 1997; Pirovano, 2012). Contrarily, few studies investigated the impact of fiscal policy on stock prices (Afonso \& Sousa, 2011, 2012; Agnello \& Sousa, 2013; Darrat, 1988; Laopodis, 2009). Additionally, some researchers have analysed the impact of monetary and fiscal policy in tandem on the economy (Dungey \& Fry, 2009; Fetai, 2013). A recent study is conducted by Chatiantonious et al., (2013) employing SVAR model using data from Germany, UK, and US. They highlighted in the study that examining the effect of monetary and fiscal policies insolation, cannot help us to reach at the truth because this type of analysis shows only the one side of the picture and unable to explain the whole phenomena. Therefore, they suggested that we should examine the impact of fiscal and monetary policies in one model to explore the contemporaneous interaction of both policies with stock prices.

\section{Literature Review}

This study endeavoured to cover the four more relevant variables blocks to examine the impact on stock returns. Therefore, the review of previous studies is also divided into four parts in the following i.e.,

\subsection{International Block and Stock Returns}

Over the last decade, the role of commodity markets (especially oil and gold) is increased recently in stock markets. On the one hand, oil market has critical role in determining the stock market returns and simultaneously it functions as a predictor of stock prices (Narayan \& Sharma, 2011; Thuraisamy et al., 2013). A large body of researchers investigated association of stock prices and oil prices using data from developed and emerging economies (Akoum et al., 2012; Aloui et al., 2012; Apergis \& Miller, 2009; Arouri et al., 2011; Arouri et al., 2013; Basher et al., 2012; Ciner et al., 2013; Fayyad \& Daly, 2011; Filis, 2010; Filis \& Chatziantoniou, 2013; Fowowe, 2013; Hammoudeh \& Choi, 2006; Lee \& Zeng, 2011; Mohanty et al., 2010; Mudakkar \& Zaman, Forthcoming; Park \& Ratti, 2008; Wang \& Chueh, 2013). By the same token, gold market is considered as a safe haven in stormy weather and hedge against risky investments. It is an ancient wisdom that gold does not lose its value and used as an investment instrument. Due to bad performance of financial markets, investors have diverted their investments in gold market and it entailed hikes in the gold prices (Baur \& McDermott, 2010; Hood \& Malik, 2013). It is noted in findings of previous studies that oil and gold prices influence the stock prices equally in all regions (Souček, Forthcoming; Thuraisamy et al., 2013). As Mensi et al. (2013) concluded that gold and oil prices have strong role in the volatility of S\&P 500. Beckmann and Czudaj (2013b) also revealed that oil and gold markets are positively influencing the prices in US. Additionally, Beckmann and Czudaj (2013a) suggested that gold acts as hedge commodity in developed markets. Similar findings are reported by Creti et al. (2013) that gold acts as a safe-haven in turmoil regime. Ewing and Malik (2013) findings suggest that information about interaction between oil and gold markets is beneficial for financial market investor for hedging. Among other international variables, oil and gold prices have significant association with stock returns. Therefore, world oil and gold prices are used in the current study.

\subsection{Property Block and Stock Returns}

Recent global boom and bust developments in house prices attracted the attention of financial researchers to investigate the dynamic behaviour of house prices (Cesa-Bianchi, 2013; Crowe et al., 2013). Prior to global crisis, the prices of house property rose unprecedently and collapsed during the financial crisis (Kose et al., 2012). The association between stock and real estate property is a contestable issue in the eyes of researchers and policy makers because of inconsistent results. Liu et al. (1990) pointed out two concepts, namely segmentation and integration about the relationship of stock prices and house prices. According to them, segmentation is a situation when investors are not earning the same expected return on house market and stock market. On the other hand, integration exists when investors is earning the similar risk-adjusted expected returns from house market and stock market. A body of researchers investigated the linkage between stock prices and house prices (e.g., Caporale \& Souza, 2011; Darrat \& Glascock, 1989; Green, 2002; Li 
\& Wang, 1995; Lin \& Lin, 2011; Ling \& Naranjo, 1999; Liu et al., 1990; Lu et al., 2007; Nawawi et al., 2010).

\subsection{Fiscal Policy Block and Stock Returns}

Influence of fiscal policy over stock market is theorized in three different stances. First is classical stance which views that expansion in fiscal policy generates the crowding out effect in the economy as the loanable fund become expensive for private sector due to high demand of funds by public. Interest initiate to surge and loanable fund become out of the reach of private sector. This situation effect economic activities negatively and resultantly to stock prices. Second is Keynesian stance that suggests that expansion in fiscal policy supportive to boost aggregate demand in economies that become the cause of positive trend in economic activities. In the result of this stock markets performance also become positive due to health corporate sector. Third is Ricardian stance that describe that role of fiscal policy is irrelevant and nothing is contributed by fiscal policy in stock prices (Afonso \& Sousa, 2011; Barro, 1979; De Castro, 2006; Giorgioni \& Holden, 2003). In a nutshell, influence of fiscal policy on stock market may be negative, positive or irrelevant (Chatiziantoniou et al., 2013).

On the other hand, literature is not reckoned the appropriate tool to estimate the fiscal policy innovations out of three, namely, borrowing, taxation, and expenditures (Afonso and Sousa, 2011). Government expenditures are used by Fatás and Mihov (2001) to capture the impact of fiscal policy shocks. Chan and Karim (2012) suggested that government expenditure has vital role in economic stability. Belo et al. (2013) also supported that government expenditures are more relevant to investigate the connectivity of fiscal policy with stock returns. In the similar fashion, Chatiaztoneous et al., (2013) used government expenditure as a measure of fiscal policy with stock returns. Valuing the above references, current study applied government expenditures as appropriate measure of fiscal policy.

Potentially fiscal policy stance has significant role in stock prices but interestingly little attention is given to explain role of fiscal policy with stock prices (Jansen et al., 2008). Theoretically, fiscal and monetary policies have mutually significant effect on stock returns as explained by Blanchard (1981). On the one side, role of monetary policy on stock returns is well documented in previous literature but it is mentioned by Canzoneri et al. (2011) that role of fiscal to determine asset prices is emphasized by researchers. But joint interaction between monetary and fiscal policy with stock prices is ignored by previous researchers and it remained neglected part of empirical literature (Agnello \& Sousa, 2010; Darrat, 1988; Jansen et al., 2008; Linnemann \& Schabert, 2004).

Interestingly, examining the effect of monetary and fiscal policies with stock price in independently is only the half picture of the story which is practically powerless to present the true picture (Chatziantonious et al., 2013). Fiscal policy influence significantly monetary policy through exchange rate and interest rate channels. Both policies interacted indirectly via different channels (e.g. inflation, deficit financing). Therefore, their interaction becomes more complex to investigate (Canzoneri et al., 2011). Furthermore, Reade (2011) highlighted that both policies are rarely investigated theoretically vis-à-vis empirically. Therefore, study of fiscal and monetary policies is fruitful to find out the stability in financial markets in addition in economies.

\subsection{Monetary Policy Block and Stock Returns}

Monetary policy and stock market relation is examined extensively by previous studies (e.g., Bjørnland \& Leitemo, 2009; Cassola \& Morana, 2004; Guo et al., 2013; Laopodis, 2013; Patelis, 1997; Pirovano, 2012; Sellin, 2001; Thorbecke, 1997). Among several channels, short-term interest rate and exchange rate channels are most relevant stock returns. These channels have feedback relation with stock return (Mishkin, 2001).

Present value model developed by Gordon (1962) which explains that stock prices are determined by the sum of future discounted cash flows. This model consists of two parts: estimated future flows and discount factor.

$$
P_{t}=E_{t}\left\{\sum_{j=1}^{K} \frac{D_{t+j}}{(1+R)^{j}}\right\}
$$

Where $P_{t}$ is denoted current price of a stock and $D_{t+j}$ is discount value of future expect cash flows over the $K$ periods. Eis express available information set at time $t$, whereas $R_{i}$ is the discount factor used for discounting future cash flows.

Therefore, interest rate channel of monetary policy determines stock prices. When monetary policy rate is changed that directly influence the discount factor (i.e. cost of capital) and eventually the discounted cash flow of the firm. Theoretically, negative relationship between interest rate channel and stock prices is hypothesized in the literature (Bjørnland \& Leitemo, 2009). Many previous studies found the similar relation empirically (Alam \& Uddin, 2009; Chen et 
al., 1986; Geske \& Roll, 1983; Lee, 1992; Sellin, 2001). On other hand, some studies among other recent studies found asymmetric results about relationship between interest rate channel of monetary policy and stock prices (e.g., Berg, 2012; Bouakez et al., 2013; Guo et al., 2013; Hsu \& Chiang, 2011; Jansen \& Tsai, 2010; Tsai, 2013; Yao et al., 2012). In next turn the second channel of monetary policy i.e., exchange rate channel is discussed.

Relationship between exchange rate and stock prices is topic interest of interest for academic researchers as well as for international portfolio investors for eighties due to liberalized global movement of capital. Theoretically, two groups of researchers which present two models that explain the relationship between both markets. First, "Flow-oriented model" that posit that stock prices are positively influenced by exchange rates. It is believed that this process is initiated by a change in price of foreign exchange. When devaluation occurs in a currency, consequent local currency to become cheaper in the international market and resultantly the exporting products of that country will also become cheaper. Therefore, if the country is export-dominate then the demand for its products becomes high, this lead to increase in exports and firm's profitability and this process ultimately leads a positive change in the stock prices (see, Dornbusch \& Fischer, 1980). Second, "Stock-oriented model" that purports that exchange rates are negatively influence by stock prices. Model states that rising trend in the stock prices attract foreign investors for investment that not only increase the demand of foreign exchange, but also appreciate exchange rates and vice versa (Branson, 1981, 1983; Frankel, 1983).

Support for flow-oriented model is found by various researchers (e.g., Abdalla \& Murinde, 1997; Chiang et al., 2000; Diamandis \& Drakos, 2011; Fang, 2002; Jiranyakul, 2011; Phylaktis \& Ravazzolo, 2005; Solnik, 1987; Wongbangpo \& Sharma, 2002). Support for stock-oriented model is found by Bartov and Bodnar (1994); Soenen and Hennigar (1988); Tai (2007); Tsai (2012); Liang et al. (2013). However, it is evident from these studies that relationship between exchange and stock prices needs consensus and therefore, it should be further investigated.

\section{Data and Methodology Description}

\subsection{Data Description}

Monthly data is collected and analysed from period January 1991 to December 2012. Seven variables namely world oil prices (WOP), gold prices (GP), government expenditure (GE), house price index (HP), short-term interest rate (IR), exchange rate (ER) and stock returns (SR) are used for analysis. All variables data is collected from reliable databases. World oil and gold prices data is retrieved from U.S. Energy Information administration (EIA) and Bank of England respectively. House prices data is retrieved from Bank for International settlement (BIS). Other series data is collected from DataStream database. Data used in analysis is seasonally adjusted and are used in natural logarithm except interest rate which is in percentages.

\subsection{Methodology}

Dynamic interaction of variables is selected from four channels, namely international channel, property channel, fiscal policy channel and monetary policy channel. Structural VAR model is employed with seven variables by selecting two variables from international channel: world oil prices, gold prices. One variable for property channel is house prices and similarly one variable for fiscal policy channel is government expenditures. Two variables are selected for monetary policy channel are short-term interest rate and real effective exchange rate and stock returns are used as an arbitrage variable. This combination of variable is chosen considering previous SVAR models as well as theoretical interaction among the variables. According to best of our knowledge this combination of variables is not examined by previous researchers.

Many studies have examined the impact of oil prices on economy as well as stock performance (Basher et al., 2012; Cavalcanti \& Jalles, 2013; Kilian \& Park, 2009). Rising oil prices increase the cost of capital; therefore, a negative relationship between oil prices and stock prices is expected. Since 2001 a persistent rise in gold prices has significantly influenced investors' behavior towards equity investment (Mulyadi et al., 2012). House property is emerged a new for last one decade and it is considered as an alternative investment channel by the investors. However, a very close relationship between house prices and equity prices is found by previous studies (Belke et al., 2008; Cheng \& Jin, 2013; Liow, 2012). Government expenditure is considered a most appropriate variable to capture the impact of fiscal policy channel (Chatziantonious et al., 2013). Short-term interest rate is believed to be a major tool for monetary policy to control the inflationary trend in the economy and influenced by fiscal policy channel and international channel as well. However, linkage of exchange rate channel with all variables is assumed in the model (Basher et al., 2012).

The general form of Structural VAR $(P)$ is presented in the following: 


$$
A_{0} y_{t}=C_{0}+\sum_{i=1}^{p} A_{i} Y_{t-1}+\varepsilon_{t}
$$

Where $y_{t}$ is a $7 \times 1$ vector for endogenous variables and $y_{t}=\left(W O P_{t}, G P_{t}, H P_{t}, G E_{t}, I R_{t}, E R_{t}, S R_{t}\right)$. A shows a $7 \times 7$ contemporaneous matrix; ${ }^{A}$ are $7 \times 7$ autoregressive coefficient matrices. ${ }^{\varepsilon}$, represents $7 \times 1$ structural disturbance vector with zero covariance. However, covariance matrix for structural disturbances can be presented in this form $E\left(\varepsilon_{t} \varepsilon_{t}^{\prime}\right)=D \equiv\left[\sigma_{1}^{2}, \sigma_{2}^{2}, \sigma_{3}^{2}, \sigma_{4}^{2}, \sigma_{5}^{2}, \sigma_{6}^{2}, \sigma_{7}^{2}\right] \times 1$. The general form model in equation (1) will be converted into reduced form model by multiply both sides of equation by $A_{0}^{-1}$ and shown as:

$y_{t}=a_{0}+B_{i} y_{t-i}+e_{t}$

Where, $a_{0}=A_{0}^{-1} c_{0}, B_{i}=A_{0}^{-1} A_{i}$, and $e_{t}=A_{0}^{-1} \varepsilon_{t}$, i.e. $\varepsilon_{t}=A_{0} e_{t} \cdot e_{t}$, the reduced form errors represent the linear function of structural errors $\varepsilon_{t}$ with a covariance matrix i.e. $E\left[e_{t} e_{t}^{\prime}\right]=A_{0}^{-1} D A_{0}^{-1^{\prime}}$.

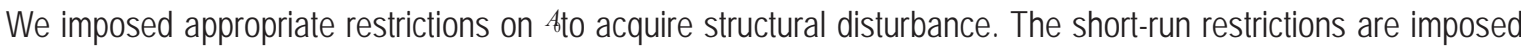
in the model in the following way:

$$
\left[\begin{array}{c}
\varepsilon_{O P} \\
\varepsilon_{G P} \\
\varepsilon_{H P} \\
\varepsilon_{G E} \\
\varepsilon_{I R} \\
\varepsilon_{E R} \\
\varepsilon_{S R}
\end{array}\right]\left[\begin{array}{ccccccc}
1 & 0 & 0 & 0 & 0 & 0 & 0 \\
a_{21} & 1 & 0 & 0 & 0 & 0 & 0 \\
0 & 0 & 1 & a_{34} & a_{35} & 0 & a_{37} \\
a_{41} & 0 & 0 & 1 & 0 & 0 & 0 \\
a_{51} & 0 & 0 & a_{54} & 1 & 0 & 0 \\
a_{61} & a_{62} & 0 & 0 & a_{65} & 1 & a_{67} \\
a_{71} & a_{72} & a_{73} & a_{74} & a_{75} & a_{76} & 1
\end{array}\right]\left[\begin{array}{c}
e_{O P} \\
e_{G P} \\
e_{H P} \\
e_{G E} \\
e_{I R} \\
e_{E R} \\
e_{S R}
\end{array}\right]
$$

where $\varepsilon_{W O P}, \varepsilon_{G P}, \varepsilon_{H P}, \varepsilon_{G E}, \varepsilon_{I R}, \varepsilon_{E R}, \varepsilon_{S R}$ are showing the structural disturbances that are gold price shocks, World oil price shocks, house price shocks, government expenditure shocks, interest rate shocks, exchange rate shocks, and stock return shocks respectively. On the other hand, $e_{W O P}, e_{G P}, e_{H P}, e_{G E}, e_{I R}, e_{E R}, e_{S R}$ are the residuals of reduced for equations that measure the unexpected movements of variables separately with the information given in the system.

Prior to explain the restrictions plan for Singaporian economy SVAR model, it is noteworthy that these restrictions are considered to be contemporaneous that were imposed on A matrix whereas no restriction is imposed on lagged structural parameters of model. First two equations of the model do not hold any restriction except $a_{21}$ being treating them as exogenous variables in the economy. It is assumed that surge in oil prices impact positively on gold prices (Reboredo, 2013). The impact of both variables is assumed for Singapore economy but no inverse impact of other variables is expected for these variables (Kim \& Roubini, 2000). Third equation is used for house prices and assumed to be influenced by government expenditures, short-term interest rate and stock returns through restrictions ${ }^{a_{34}}, a_{35}$ and $a_{37}$ respectively. Major part of government spending is concentrated on housing development in Singapore and therefore $a_{34}$ is imposed to examine the impact of government expenditures on house prices (Afonso \& Sousa, 2009). Current interest rate is an important determinent of house prices (Elbourne, 2008). The borrowing cost is increased due to increase in interest rate that leads to fall in demand for property resulting decrease in prices. Additionally, rising interest rates increase the default in mortgage payment and households start to sell their house property and supply side of house property push down the house prices (Nneji et al., 2013). Making an allowance for wealth effect hypotheses, equity market leads changes in house prices. Therefore, impact of stock prices is included in this equation. In fourth equation, Impact of fiscal policy is measured through government expenditures as it is used by previous research because there is no consensus that which one of measures (i.e., borrowing, taxation and expenditures) is appropriate to examine the impact of fiscal policy shocks (see, Afonso and Sousa, 2011). In this equation, impact of world oil prices is included using $a_{41}$ restriction as the rise in oil prices negatively influences the government expenditures and government face difficult to maintain its expansionary fiscal policy and budget deficit is increased due to higher government expenditures (Benedictow et al., 2013; Cologni \& Manera, 2013). In fifth equation, interest rate channel of monetary policy is used. Oil prices restriction through $a_{51}$ is imposed because it is considered that oil prices impact contemporaneously to short-term interest rates similar restrictions are imposed by (Cologni \& Manera, 2009). Currently expansionary fiscal policy exists in Singapore which impulses in the interest rates. Three responses are expected (classical, Keynesian, and Ricardian) are theorized in literature (details, Chatiziantoniou et al., 2013). Therefore, Restriction $a_{54}$ is used to capture the impact of fiscal policy (through government expenditures) on interest rate channel of monetary policy. Equation six represents exchange rate channel of monetary policy and four restrictions ${ }^{a_{61}}, a_{62}, a_{65}$ and $a_{67}$ are imposed. Theoretical relation 
between exchange rates and oil prices is assumed due to changes in current account balance and transfer of wealth from oil-importing countries to oil exporting countries, therefore, this contemporaneous effect of oil price changes through ${ }^{a_{61}}$ is empirically investigated (Bashir et al., 2012). Similarly, gold price changes have contemporaneous effect on exchange rates and these innovations are capture through $a_{62}$ (Han et al., 2012). Gold is used as hedge against currency markets and protect the investors from loss of devaluation. However, a negative relation is expected for exchange rate and gold price (Ciner et al., 2013). Interest rate and exchange rates are closely related due to uncovered interest rate parity which investigated using $a_{65}$ restriction. Interdependency exist between exchange rates and equity prices as explained in Floworient model vis-à-vis Stock-orient model and this linkage is measured through $a_{67}$ (Phylaktis and Ravazzalo, 2005 for detail). In the last equation, it is supposed that all above variables contemporaneously influence the stock returns (Bjornland, 2008; Chatziantoniou et al., 2013).

The IS-LM frame suggests that stock market activities are interrelated with fiscal and monetary policy actions through interest rate and government spending. Changes in policy and interest rates instantaneously force the investors to revise their portfolios because of change carried out through tightening or easing the policy (Geraldo, 2012). Exchange rates and short-run interest rates are key monetary transmission channels that influence the stock prices in ASEAN-5 countries. Therefore, it is suggested that Impulse Response Function (IRF) should be used to examine to identify the impact of shocks when they appear (Poon, 2010). In post crisis, ASEAN-4 accumulated foreign exchange reserves to resolve the panic in financial stability. The returns on these funds provided a strong support to government expenditures for these countries to regain economic momentum as before crisis. However, the positive impact of government expenditure is expected for financial stability (Park \& Estrada, 2011).

\section{Empirical Findings}

First of all lag-length order of variables is determined for analysis. Normally, information criteria are used to determine the lag-length order of variables. But econometrics theory shows a picture of controversy about the selection of appropriate lag length order for VAR models (Gredenhoff \& Karlsson, 1999; Hafer \& Sheehan, 1989; Thoma, 2008). Amongst all information criteria Final Prediction Error (FPE), Akaike Information Criterion (AIC), Schwarz Information Criterion (SIC), and Hannan-Quinn information criterion $(\mathrm{HQ})$ are widely used by the researchers. While debating on the above mentioned criteria, Brooks (2008) pointed that there is no concrete principle for the selection of superior information criteria as some of the information criteria are efficient but not consistent, while others are consistent but not efficient. The results of lag length according to information criteria are mentioned in Table 1.

Table 1: Lag Length results according Information criteria

\begin{tabular}{|c|c|c|c|c|c|c|}
\hline Lag & LogL & LR & FPE & AIC & SC & HQ \\
\hline 0 & 149.7113 & NA & $7.63 \mathrm{e}-10$ & -1.128152 & -1.030391 & -1.088819 \\
\hline 1 & 2356.523 & 4274.063 & $2.98 \mathrm{e}-17$ & -18.18596 & -17.40386 & -17.87129 \\
\hline 2 & 2646.732 & 546.0050 & $4.44 \mathrm{e}-18^{\star}$ & $-20.09274^{*}$ & $-18.62632^{\star}$ & $-19.50275^{\star}$ \\
\hline 3 & 2683.786 & 67.66473 & $4.88 \mathrm{e}-18$ & -19.99831 & -17.84755 & -19.13299 \\
\hline 4 & 2719.029 & 62.40501 & $5.47 \mathrm{e}-18$ & -19.88955 & -17.05446 & -18.74890 \\
\hline 5 & 2761.800 & 73.37056 & $5.78 \mathrm{e}-18$ & -19.84032 & -16.32089 & -18.42433 \\
\hline 6 & 2799.943 & 63.32022 & $6.36 \mathrm{e}-18$ & -19.75449 & -15.55073 & -18.06318 \\
\hline 7 & 2828.985 & 46.60460 & $7.55 \mathrm{e}-18$ & -19.59672 & -14.70863 & -17.63007 \\
\hline 8 & 2888.446 & $92.12966^{*}$ & $7.08 \mathrm{e}-18$ & -19.67941 & -14.10699 & -17.43744 \\
\hline
\end{tabular}

* indicates lag order selected by the criterion

Cheung and Lai (1993) criticized information criteria methods for selection of optimal lag length by arguing that information criteria do not perform well in empirical analysis when data series are representing moving average dependence. Based on the above mentioned information and criticism, information criteria procedure is not considered as an appropriate criterion to determine lag length as it may lead to poor performance, inefficiency and inconsistency. Instead, Hall (1989) and Johansen (1992) are of the view that the stage where VAR residuals are not serially correlated is the best point to select lag length order. On the other hand, selection of low or high lag lengths are not problem free as low lag length leads to the problem of serial correlation, whereas high lag length leads to the problem of finite sample bias (Hall, 1991). Current study applied information criteria method vis-à-vis residual test. Thus, based on above arguments about selection of appropriate lag length, the present study used lag orders where VAR residuals are serially uncorrelated 
and these lag lengths are varying country wise using residual test in accordance with (Ibrahim, 2006). Examining the residual tests lag 8 is selected for analysis.

Going ahead for SVAR analysis, stationary of the variables was estimated through ADF and PP tests. A problem of unit root was found in the variables except stock returns and results are presented in Table 2. Following the practice of previous researchers, level series are preferred by researchers to maintain consistency on the cost of efficiency. They argued that most of the information is lost if stationary series with differences are used in analysis (Basher et al., 2012; Pirovano, 2012).

Table 2: Testing for unit roots (ADF and PP tests)

\begin{tabular}{|c|c|c|c|c|}
\hline & \multicolumn{2}{|c|}{ Augmented Dickey Fuller Test } & \multicolumn{2}{c|}{ Philip Perron Test } \\
\hline Variables & Level & 1st Difference & Level & 1st Difference $^{\text {st }}$ \\
\hline OP & 0.52 & $-18.31^{*}$ & -0.43 & $-18.22^{\star}$ \\
\hline GP & 2.37 & $-13.97^{*}$ & 1.74 & $-18.59^{\star}$ \\
\hline HP & -2.15 & $-4.03^{\star}$ & -2.33 & $-4.38^{\star}$ \\
\hline GE & -1.64 & $-14.77^{*}$ & $-3.48^{\star}$ & $-86.95^{\star}$ \\
\hline IR & -2.20 & $-12.65^{\star}$ & -2.27 & $-14.53^{\star}$ \\
\hline ER & -0.41 & $-15.71^{*}$ & -0.43 & $-15.71^{\star}$ \\
\hline SR & $-13.47^{*}$ & $-10.85^{\star}$ & $-13.45^{\star}$ & $-65.24^{\star}$ \\
\hline
\end{tabular}

*significant at 1 percent level

\subsection{Results for Contemporaneous restrictions}

The likelihood test of over-identification restriction test shows chi-square value $\left(\chi^{2}(4)=0.66\right)$ with significance level of 95.61 percent that means that the over-identification restrictions cannot be rejected at any conventional significance level. Contemporaneous coefficients with standard error are presented in Table 3.

Table 3: Summary of Contemporaneous Coefficients

\begin{tabular}{|c|c|c|c|c|c|c|c|c|}
\hline$a_{21}$ & $a_{34}$ & $a_{35}$ & $a_{37}$ & $a_{41}$ & $a_{51}$ & $a_{54}$ & $a_{61}$ & $a_{62}$ \\
\hline-2.9419 & -3.6667 & -0.1400 & 5.5120 & -0.5543 & -0.5439 & 1.9481 & 0.6886 & 7.5634 \\
$(0.9211)$ & $(11.1546)$ & $(0.0953)$ & $(12.1877)$ & $(0.9120)$ & $(0.9126)$ & $(0.0597)$ & $(1.1938)$ & $(1.6310)$ \\
\hline$a_{65}$ & $a_{67}$ & $a_{71}$ & $a_{72}$ & $a_{73}$ & $a_{74}$ & $a_{75}$ & $a_{76}$ \\
\hline-0.0585 & -3.5989 & -1.5293 & 1.1706 & -9.1127 & -1.1549 & 0.0760 & 2.8463 \\
$(0.0886)$ & $(10.3297)$ & $(0.9935)$ & $(3.9987)$ & $(36.4736)$ & $(11.3196)$ & $(0.1309)$ & $(23.5612)$ \\
\hline
\end{tabular}

This study focused on four blocks of variables (international block, house property block, monetary block and fiscal block). Two important variables from international block are used i.e. oil price and gold price. While, only single contemporaneous restriction $a_{21}$ is imposed to examine the impact of oil price on gold price. Co-efficient is -2.9419 (note that this sign is negative because restrictions are imposed on Amatrix which is on left-hand side of the equation (1). When it is shifted on right-hand side of equation, this negative sign will be changed to positive) (see, Badshah et al., 2013). Coinciding movement of both variables has already identified by the previous studies and inflation is identified the reason behind this identical movement (Reboredo, 2013; Souček, Forthcoming). However, it is hypothesized that oil price has positive impact on commodity prices including gold price. There are a number of reasons for hike in gold price and one of them is surge in oil prices and therefore, gold is used as a hedge against inflation. The results of the present study are in accordance with previous studies as they also noted a positive impact of oil price on gold prices (Beckmann \& Czudaj, 2013b; Le \& Chang, 2011; Zhang \& Wei, 2010). Additionally, contemporaneous impact of oil price is also examined on government expenditures, short-term interest rates, exchange rates and stock returns through ${ }^{a_{41}}, a_{51}, a_{61}$ and $a_{71}$ respectively. Positive impact of oil price on government expenditures and short-term interest rate is investigated which indicates that upsurge in oil prices causes inflation. When already economy is facing inflation pressure, the expansion in fiscal expenditures inflation put more fire in the fuel (Ayadi, 2005; Farzanegan, 2011; Hamdi \& Sbia, 2013). Negative influence of oil prices on exchange rate is found in Singapore. Similar effect is reported by (Narayan et al., 2008) while studying the impact of oil prices on exchange rate using data from Fiji and results derived by (Turhan et al., 2013) are also in accordance with this finding. Positive impact of oil prices on stock returns is observed through high profitable level which raises the stock price (Wang et al., Forthcoming). Second international variable is gold prices. Contemporaneous impact of gold prices is observed on exchange rates and stock returns through $a_{62}$ and $a_{72}$. Relationship between 
exchange rate and gold prices is found to be negative which is the evidence of hedge against the currency. Inverse relation of exchange rate and gold prices is found by (Joy, 2011). Relationship between gold price and stock returns is found to be negative that clear shows that gold is used as hedge against stocks and similar result are witnessed by various previous studies (e.g., Baur \& Lucey, 2010; Hillier et al., 2006; Hood \& Malik, 2013; Miyazaki \& Hamori, 2013). Impact of house property block is examined through house price variable. Contemporaneous impact of house price is investigated on stock returns using ${ }^{a_{33}}$ restriction. Results revealed a positive impact of house price on stock returns. This result suggests that house property income has positive effect on stock prices whereas negative impact of stock returns is visualized in the results using $a_{37}$ which show the evidence of stock wealth has no effect on house property. It can be derived that surplus earned by equity investors are invested in housing market (Hui \& Ng, 2012; Peltonen et al., 2012). In fiscal policy block, government expenditures are used as a fiscal variable because recently, every economy focuses on fiscal package to promote the economic growth to redress the evils of financial panic. Impact of government expenditures is also applied on house price, interest rates and stock returns via restrictions ${ }^{a^{34}}, a_{54}$ and $a{ }^{4}$ respectively. Results identified that government expenditures influence positively to house prices and stock returns and negatively to interest rates. These results are in the favour of Keynesian stance (Belo et al., 2013; Dungey \& Fry, 2009).

Monetary block encompasses interest rates and exchange rate. Contemporaneous impact of interest rate is analysed with house prices, exchange rates and stock returns via $a_{35} a_{65} a_{75}$ respectively. Positive impact of interest rate is observed on house prices. This result is puzzling for Singapore because house prices are increasing but interest is low. Therefore, both variables are inversely related which are presented by results (Aoki et al., 2004; Tsai, 2013). Result $a_{65}$ is presenting positive results which are not strange for Singapore because exchange rate is adjusted according to interest rate. Restriction $a_{75}$ is showing negative relationship between interest rate and stock return which is desirable and in accordance with theory (Pirovano, 2012). Relationship between exchange rate and stock return is examined through $a_{67}$ and ${ }^{a_{76}}$. These restrictions are helpful to investigate the impact of both models ("Flow-oriented and Stock-oriented). When a country is leading in exports, it causes an appreciation of the currency leading towards increased firm's profitability but negatively affecting exchange rates. However, Singapore is net exporter country; therefore this relationship is not surprising for this country.

\subsection{Impulse Responses}

The section covers impulse response function in respect of oil price, gold price, house price, government expenditures, interest rate, exchange rate and stock return and these shocks are shown in Figure 2. Oil prices are assumed to have contemporaneous impact on gold prices, government expenditures, interest rates, exchange rates, and stock returns. Oil prices show constant positive impact on gold and short-term interest rate throughout the horizon but the immediate impact on exchange rate is negative up to 6 months after that effect become positive for rest of the time horizon. However, initial oil price impact on government expenditure is very low which becomes negative onward; whereas, stock returns demonstrate contemporaneous increase in early three months and afterward convert to negative and get weaker with the passage of time. These shocks show that oil price has strong influence on these variables. Similarly, gold prices are assumed to have contemporaneous effect on exchange rate and stock returns. Negative innovation appears in exchange rates and going to weak gradually at the end of horizon. Stock returns demonstrated positive response to gold price up to 7 months and in follow up diverted negatively and get weaker till the end of horizon. House prices exerted positive impact on interest rates within first 10 months and subsequently, it continues to move forward positively but very close to zero. It is evident that influence of house prices is not significant on stock returns. Influence of government expenditure used as proxy for fiscal policy is hypothesized on house price, interest rate, and stock returns. Results demonstrate that government expenditures reveal positive impact on house prices with lag of two months and this impact shows rising trend up to end of horizon. Contrarily, government expenditure display negative shocks in short-term interest consistently and impact on stock returns is hybrid over the horizon, but negative impact becomes strong during 4 to 7 months. Short-term interest is used as a proxy for monetary policy implementations. It is assumed in the SVAR baseline model that interest rate impacts house prices, exchange rates and stock returns instantaneously. Impulse response displays that short-term interest rate innovation has positive impact on house price for initial 10 months. However, exchange rates demonstrated a positive response to interest rate in the entire horizon except with a downfall in sixth month, whereas stock returns show hybrid reaction in earlier 10 months and subsequently a positive but weak response continue till sixth months and after that it remain close to zero at the end of horizon. Contemporaneous influence of exchange rate is assumed on stock returns. Result displayed a heterogeneous response of stock returns to exchange rates. Finally, it was hypothesized that stock returns impact contemporaneously to house prices and exchange rates. 
Hence, reaction of house price is negative in early four months and subsequently this response changed and become positive to continue till the end of horizon. On the other hand, response of exchange rates is positive and this response die away at the end of horizon. Positive response is in the favour of "flow-oriented model".

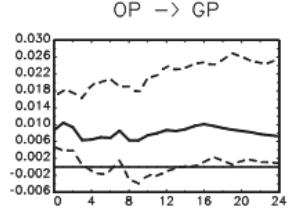

OP $\rightarrow I R$

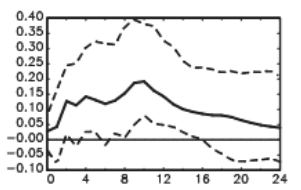

$\mathrm{OP} \rightarrow \mathrm{SR}$

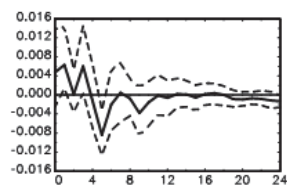

$\mathrm{GP} \rightarrow \mathrm{SR}$

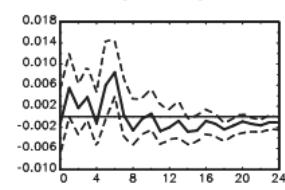

$\mathrm{GE} \rightarrow \mathrm{HP}$

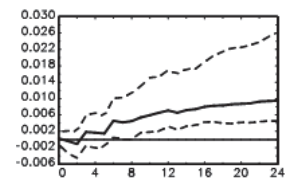

$\mathrm{GE} \rightarrow \mathrm{SR}$

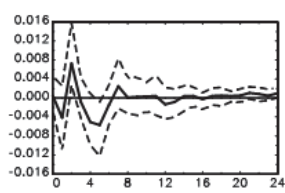

IR $\rightarrow$ ER

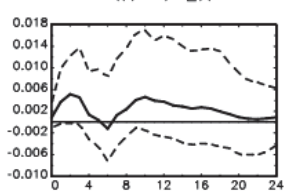

$E R \rightarrow S R$

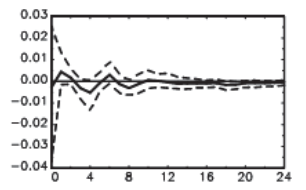

$\mathrm{OP} \rightarrow \mathrm{GE}$

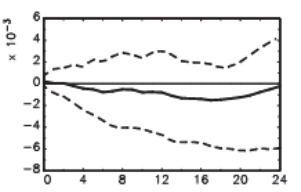

$O P \rightarrow E R$

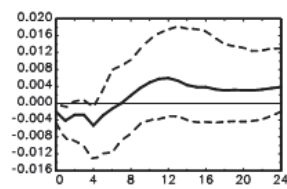

GP $\rightarrow$ ER

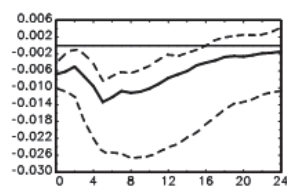

$\mathrm{HP} \rightarrow \mathrm{SR}$

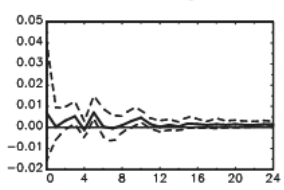

$\mathrm{GE} \rightarrow>\mathrm{IR}$

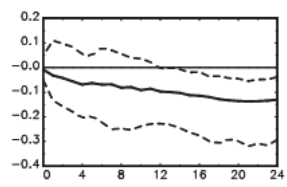

$\mid \mathrm{R} \rightarrow \mathrm{HP}$

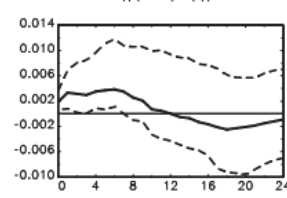

IR $\rightarrow$ SR

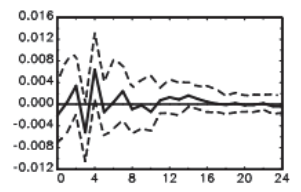

$\mathrm{SR} \rightarrow \mathrm{HP}$

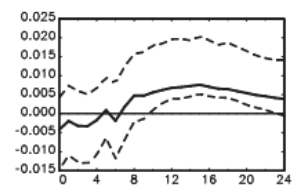

$S R->E R$

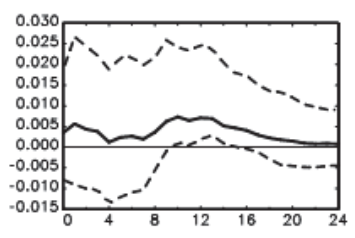

Figure 2: Impulse Responses in Singapore 


\subsection{Variance Decomposition}

Variance decomposition (VDC) is used to split overall changes in a variable caused by other variables. Table 4 represents the detail of variance decomposition results covering period of 24 months with four six monthly intervals.

Table 4: Variance Decomposition: Basic SVAR Model-Singapore

\begin{tabular}{|c|c|c|c|c|c|c|c|c|}
\hline VAR Decomposition & Period & OP & GP & HP & GE & IR & ER & SR \\
\hline \multirow{4}{*}{$\mathrm{HP}$} & 6 & 0.00 & 0.00 & 0.24 & 0.01 & 0.23 & 0.04 & 0.49 \\
\hline & 12 & 0.00 & 0.01 & 0.16 & 0.06 & 0.38 & 0.04 & 0.35 \\
\hline & 18 & 0.00 & 0.01 & 0.11 & 0.11 & 0.46 & 0.03 & 0.27 \\
\hline & 24 & 0.03 & 0.03 & 0.08 & 0.16 & 0.44 & 0.02 & 0.24 \\
\hline \multirow{4}{*}{ GE } & 6 & 0.00 & 0.00 & 0.01 & 0.97 & 0.00 & 0.00 & 0.01 \\
\hline & 12 & 0.01 & 0.01 & 0.04 & 0.88 & 0.00 & 0.02 & 0.05 \\
\hline & 18 & 0.01 & 0.02 & 0.04 & 0.83 & 0.00 & 0.04 & 0.05 \\
\hline & 24 & 0.01 & 0.04 & 0.03 & 0.79 & 0.01 & 0.07 & 0.05 \\
\hline \multirow{4}{*}{ IR } & 6 & 0.04 & 0.00 & 0.73 & 0.01 & 0.01 & 0.09 & 0.12 \\
\hline & 12 & 0.09 & 0.01 & 0.59 & 0.02 & 0.02 & 0.18 & 0.10 \\
\hline & 18 & 0.10 & 0.03 & 0.54 & 0.04 & 0.02 & 0.17 & 0.10 \\
\hline & 24 & 0.10 & 0.04 & 0.51 & 0.07 & 0.02 & 0.15 & 0.10 \\
\hline \multirow{4}{*}{ ER } & 6 & 0.02 & 0.09 & 0.01 & 0.03 & 0.01 & 0.83 & 0.01 \\
\hline & 12 & 0.02 & 0.13 & 0.00 & 0.03 & 0.01 & 0.74 & 0.07 \\
\hline & 18 & 0.02 & 0.13 & 0.00 & 0.03 & 0.01 & 0.71 & 0.10 \\
\hline & 24 & 0.03 & 0.12 & 0.01 & 0.03 & 0.02 & 0.69 & 0.12 \\
\hline \multirow{4}{*}{ SR } & 6 & 0.06 & 0.03 & 0.11 & 0.04 & 0.59 & 0.02 & 0.14 \\
\hline & 12 & 0.06 & 0.06 & 0.11 & 0.04 & 0.56 & 0.03 & 0.14 \\
\hline & 18 & 0.06 & 0.06 & 0.11 & 0.04 & 0.56 & 0.03 & 0.14 \\
\hline & 24 & 0.06 & 0.06 & 0.11 & 0.04 & 0.55 & 0.03 & 0.14 \\
\hline
\end{tabular}

Note: $\mathrm{OP}=\mathrm{Oil}$ Price; GP=Gold Price; HP=House Price; GE=Government Expenditure; IR=Interest Rate; ER=Exchange Rate; SR=Stock Return

Variance decomposition of house prices, government expenditure, interest rate, exchange rate and stock returns is estimated in analysis. House prices are showing significant change of $23 \%$ and $49 \%$ in first interval through interest rates and stock returns respectively. Changes by interest rate are increased in each subsequent interval and its contribution is $44 \%$ in last interval but changes by stock returns show downward trend which $24 \%$ in fourth interval. Government expenditure demonstrated small change in house prices, but increased gradually and reached at $16 \%$ in fourth interval. Oil price, gold price, and exchange rate made invisible changes in house prices.

Government expenditure is showing a constant change of $5 \%$ by stock returns. Other variables are not showing any notable change except exchange rate which increased up to $7 \%$ in fourth interval. However, all change in government expenditure is its own. It is notable that all variables are affecting interest rate with different portion but house price has significant effect of $73 \%$ in first interval and decreased up to $51 \%$ in last interval. Oil price effect is $4 \%$ in first interval and rose to $10 \%$ in fourth interval. Similarly, government expenditure and exchange rate effects are $7 \%$ and $15 \%$ in last interval whereas stock returns are showing constant effect i.e. $10 \%$. In case of exchange rate, only gold price is showing notable effect of $12 \%$ and stock returns contribution increased to $12 \%$ in last interval and other variables have not demonstrated any visible change in this variable. However, all variables are influencing stock returns and it is interesting that each variable innovation has constant effect on this variable. Out of these, interest rate has significant effect of $56 \%$ over the horizon. Oil prices and gold prices have similar effect at the rate of $6 \%$ whereas house price, government expenditure and exchange rate have very minor effect of $11 \%, 4 \%$, and $3 \%$ respectively.

\section{Conclusion}

The selected monetary and fiscal policy variables were analysed in tandem with stock returns. Short-term interest rate and exchange rate are used as monetary policy variables while government expenditure is used for fiscal policy. Gold and oil prices are included with house prices. Gold prices, oil prices and house markets' importance have increase recently because of their influence in financial markets and crucial impact on economy growth. Impact of oil price is 
significant increased on gold prices and monetary \& fiscal policies variables are also influenced by oil prices. In case of house prices, government expenditure has significant effect to make positive change in house prices. Interaction of monetary and fiscal did not prove any crowding out effect. Significant wealth effect on house prices by stock returns but house prices impact is very weak on stock returns. Interaction of exchange rate and stock prices is supporting the portfolio model as foreign direct investment is encouraging in the economy. The current study is helpful to account instant information to enhance the understanding of government macroeconomic policy makers vis-a-vis the prospective and existing investors. In future, investors and policy makers should contemplate the impact of monetary and fiscal policies jointly to strength the financial markets, especially, considering interaction between house and stock markets in Singapore.

\section{References}

Abdalla, I. S. A., \& Murinde, V. (1997). Exchange rate and stock price interactions in emerging financial markets: evidence on India, Korea, Pakistan and the Philippines. Applied Financial Economics. 7(1), 25-35.

Afonso, A., \& Sousa, R. M. (2009). Fiscal policy, housing and stock prices. European Central Bank working paper series no 990-2009, 143.

Afonso, A., \& Sousa, R. M. (2011). What are the effects of fiscal policy on asset markets? Economic Modelling. 28(4), 1871-1980.

Afonso, A., \& Sousa, R. M. (2012). The macroeconomic effects of fiscal policy. Applied Economics. 44(34), 4439-4454.

Agnello, L., \& Sousa, R. M. (2010). Fiscal policy and asset prices. WP 25/2010, 1-37.

Agnello, L., \& Sousa, R. M. (2013). Fiscal Policy and Asset Prices. Bulletin of Economic Research. 65(2), 154-177.

Akoum, I., Graham, M., Kivihaho, J., Nikkinen, J., \& Omran, M. (2012). Co-movement of oil and stock prices in the GCC region: A wavelet analysis. The Quarterly Review of Economics and Finance. 52(4), 385-394.

Alam, M. M., \& Uddin, M. G. S. (2009). Relationship between interest rate and stock price: empirical evidence from developed and developing countries. International journal of business and management. 4(3), P43.

Aloui, C., Nguyen, D. K., \& Njeh, H. (2012). Assessing the impacts of oil price fluctuations on stock returns in emerging markets. Economic Modelling. 29(6), 2686-2695.

Aoki, K., Proudman, J., \& Vlieghe, G. (2004). House prices, consumption, and monetary policy: a financial accelerator approach. Journal of Financial Intermediation. 13(4), 414-435.

Apergis, N., \& Miller, S. M. (2009). Do structural oil-market shocks affect stock prices? Energy Economics. 31(4), 569-575.

Arouri, M. E. H., Jouini, J., \& Nguyen, D. K. (2011). Volatility spillovers between oil prices and stock sector returns: Implications for portfolio management. Journal of International Money and Finance. 30(7), 1387-1405.

Arouri, M. E. H., Jouini, J., \& Nguyen, D. K. (2013). On the relationship between world oil prices and GCC stock markets. HAL: hal00798037, version 1, 1-22.

Ayadi, O. F. (2005). Oil price fluctuations and the Nigerian economy. OPEC review. 29(3), 199-217.

Badshah, I. U., Frijns, B., \& Tourani-Rad, A. (2013). Contemporaneous Spill-Over Among Equity, Gold, and Exchange Rate Implied Volatility Indices. Journal of Futures Markets. 33(6), 555-572.

Barro, R. J. (1979). Second Thoughts on Keynesian Economics. The American Economic Review. 69(2), 54-59.

Bartov, E. L. I., \& Bodnar, G. M. (1994). Firm Valuation, Earnings Expectations, and the Exchange-Rate Exposure Effect. The journal of Finance. 49(5), 1755-1785.

Basher, S. A., Haug, A. A., \& Sadorsky, P. (2012). Oil prices, exchange rates and emerging stock markets. Energy Economics. 34(1), 227-240.

Baur, D. G., \& Lucey, B. M. (2010). Is Gold a Hedge or a Safe Haven? An Analysis of Stocks, Bonds and Gold. Financial Review. 45(2), 217-229.

Baur, D. G., \& McDermott, T. K. (2010). Is gold a safe haven? International evidence. Journal of Banking \& Finance. 34(8), 1886-1898.

Beckmann, J., \& Czudaj, R. (2013a). Gold as an inflation hedge in a time-varying coefficient framework. The North American Journal of Economics and Finance. 24(0), 208-222.

Beckmann, J., \& Czudaj, R. (2013b). Oil and gold price dynamics in a multivariate cointegration framework. International Economics and Economic Policy, 1-16.

Belke, A., Orth, W., \& Setzer Jr, R. (2008). Sowing the seeds for the subprime crisis: does global liquidity matter for housing and other asset prices? International economics and economic policy. 5(4), 403-424.

Belo, F., Gala, V. D., \& Li, J. (2013). Government spending, political cycles, and the cross section of stock returns. Journal of Financial Economics. 107(2), 305-324.

Benedictow, A., Fjærtoft, D., \& Løfsnæs, O. (2013). Oil dependency of the Russian economy: An econometric analysis. Economic Modelling. 32(0), 400-428.

Berg, T. (2012). Did monetary or technology shocks move euro area stock prices? Empirical Economics. 43(2), 693-722.

Bhuiyan, R. (2012). Monetary transmission mechanisms in a small open economy: a Bayesian structural VAR approach. Canadian Journal of Economics/Revue canadienne d'économique. 45(3), 1037-1061.

Bjørnland, H. C., \& Leitemo, K. (2009). Identifying the interdependence between US monetary policy and the stock market. Journal of Monetary Economics. 56(2), 275-282. 
Blanchard, O. J. (1981). Output, the stock market, and interest rates. The American Economic Review. 71(1), 132-143.

Bouakez, H., Essid, B., \& Normandin, M. (2013). Stock returns and monetary policy: Are there any ties? Journal of Macroeconomics. 36(0), 33-50.

Branson, W. H. (1981). Macroeconomic determinants of real exchange rates: National Bureau of Economic Research Cambridge, Mass., USAo. Document Number)

Branson, W. H. (1983). A model of exchange-rate determination with policy reaction: evidence from monthly data: National Bureau of Economic Research Cambridge, Mass., USAo. Document Number)

Brooks, C. (2008). Introductory econometrics for finance. Cambridge university press.

Canzoneri, M., Cumby, R., \& Diba, B. (2011). The interaction between monetary and fiscal policy. Handbook of monetary economics. 3 , 935-999.

Caporale, G. M., \& Souza, R. M. (2011). Consumption, wealth, stock and housing returns: evidence from emerging markets: Discussion Papers, German Institute for Economic Research, DIW Berlino. Document Number)

Cassola, N., \& Morana, C. (2004). Monetary policy and the stock market in the euro area. Journal of Policy Modeling. 26(3), 387-399.

Cavalcanti, T., \& Jalles, J. T. (2013). Macroeconomic effects of oil price shocks in Brazil and in the United States. Applied Energy. 104(0), 475-486.

Cesa-Bianchi, A. (2013). Housing cycles and macroeconomic fluctuations: A global perspective. Journal of International Money and Finance. 37(0), 215-238.

Challe, E., \& Giannitsarou, C. (2012). Stock prices and monetary policy shocks: A general equilibrium approach.

Chan, S.-G., \& Karim, M. A. Z. (2012). Public spending efficiency and political and economic factors: Evidence from selected East Asian countries. Ekonomski anali. 57(193), 7-23.

Chatziantoniou, I., Duffy, D., \& Filis, G. (2013). Stock market response to monetary and fiscal policy shocks: Multi-country evidence. Economic Modelling. 30(0), 754-769.

Chen, N. F., Roll, R., \& Ross, S. A. (1986). Economic forces and the stock market. Journal of business, 383-403.

Cheng, L., \& Jin, Y. (2013). Asset prices, monetary policy, and aggregate fluctuations: An empirical investigation. Economics Letters. $119,24-27$.

Cheung, Y.-W., \& Lai, K. S. (1993). Finite-Sample Sizes of Johansen's Likelihood Ratio Tests for Cointegration. Oxford Bulletin of Economics and Statistics. 55(3), 313-328.

Chiang, T. C., Yang, S. Y., \& Wang, T. S. (2000). Stock return and exchange rate risk: evidence from Asian stock markets based on a bivariate GARCH model. International Journal of Business. 5(2), 97-117.

Ciner, C., Gurdgiev, C., \& Lucey, B. M. (2013). Hedges and safe havens: An examination of stocks, bonds, gold, oil and exchange rates. International Review of Financial Analysis. 29(0), 202-211.

Cologni, A., \& Manera, M. (2009). The asymmetric effects of oil shocks on output growth: A Markov-Switching analysis for the G-7 countries. Economic Modelling. 26(1), 1-29.

Cologni, A., \& Manera, M. (2013). Exogenous oil shocks, fiscal policies and sector reallocations in oil producing countries. Energy Economics. 35(0), 42-57.

Credit-suisse. (2013). Singapore as a Financial Hub. Retrieved 10/12/2013, from https://www.credit-suisse.com/sg/privatebanking/ bank/en/financialhub.jsp

Creti, A., Joëts, M., \& Mignon, V. (2013). On the links between stock and commodity markets' volatility. Energy Economics. 37(0), 16-28.

Crowe, C., Dell'Ariccia, G., Igan, D., \& Rabanal, P. (2013). How to deal with real estate booms: Lessons from country experiences. Journal of Financial Stability. 9(3), 300-319.

Darrat, A. F. (1988). On Fiscal Policy and the Stock Market. Journal of Money, Credit and Banking. 20(3), 353-363.

Darrat, A. F., \& Glascock, J. L. (1989). Real estate returns, money and fiscal deficits: Is the real estate market efficient? The Journal of Real Estate Finance and Economics. 2(3), 197-208.

De Castro, F. (2006). The macroeconomic effects of fiscal policy in Spain. Applied Economics. 38(8), 913-924.

Dfat. (2013). Singapor Country Brief. Retrieved 10/12/2013, from http://www.dfat.gov.au/geo/singapore/singapore_country_brief.html

Diamandis, P. F., \& Drakos, A. A. (2011). Financial liberalization, exchange rates and stock prices: Exogenous shocks in four Latin America countries. Journal of Policy Modeling. 33(3), 381-394.

Dornbusch, R., \& Fischer, S. (1980). Exchange Rates and the Current Account. The American Economic Review. 70(5), 960-971.

Dungey, M., \& Fry, R. (2009). The identification of fiscal and monetary policy in a structural VAR. Economic Modelling. 26(6), 1147-1160.

Elbourne, A. (2008). The UK housing market and the monetary policy transmission mechanism: An SVAR approach. Journal of Housing Economics. 17(1), 65-87.

Ewing, B. T., \& Malik, F. (2013). Volatility transmission between gold and oil futures under structural breaks. International Review of Economics \& Finance. 25(0), 113-121.

Fang, W. (2002). The effects of currency depreciation on stock returns: evidence from five East Asian economies. Applied Economics Letters. 9(3), 195-199.

Farzanegan, M. R. (2011). Oil revenue shocks and government spending behavior in Iran. Emergy. 33, 1055-1069.

Fatás, A., \& Mihov, I. (2001). Government size and automatic stabilizers: international and intranational evidence. Journal of International Economics. 55(1), 3-28.

Fayyad, A., \& Daly, K. (2011). The impact of oil price shocks on stock market returns: comparing GCC countries with the UK and USA. Emerging Markets Review. 12(1), 61-78. 
Fetai, B. (2013). Assessing Monetary and Fiscal Policy Interaction in a Small Open Economy: the Case Republic of Macedonia. Transition Studies Review. 20(1), 89-104.

Filis, G. (2010). Macro economy, stock market and oil prices: Do meaningful relationships exist among their cyclical fluctuations? Energy Economics. 32(4), 877-886.

Filis, G., \& Chatziantoniou, I. (2013). Financial and monetary policy responses to oil price shocks: evidence from oil-importing and oilexporting countries. Review of Quantitative Finance and Accounting, 1-21.

Fowowe, B. (2013). Jump dynamics in the relationship between oil prices and the stock market: Evidence from Nigeria. Energy. 56(0), 31-38.

Frankel, J. (1983). Monetary and portfolio-balance models of exchange rate determination, in economic interdependence and flexible exchange rates. Cambridge, MA: MIT Press.[Links].

Galí, J., \& Gertler, M. (2007). Macroeconomic Modeling for Monetary Policy Evaluation. The Journal of Economic Perspectives. 21(4), 25-46.

Geraldo, E. Y. (2012). Fiscal Policy, Monetary Policy and Stock Market Activity in Ghana (Doctoral dissertation). Kwame Nkrumah University of Science and Technology.

Geske, R., \& Roll, R. (1983). The Fiscal and Monetary Linkage between Stock Returns and Inflation. The journal of Finance. 38(1), 1-33.

Giorgioni, G., \& Holden, K. (2003). Ricardian equivalence, expansionary fiscal contraction and the stock market: a VECM approach. Applied Economics. 35(12), 1435-1443.

Gordon, M. J. (1962). The Savings Investment and Valuation of a Corporation. The Review of Economics and Statistics. 44(1), 37-51.

Gredenhoff, M., \& Karlsson, S. (1999). Lag-length selection in VAR-models using equal and unequal lag-length procedures. Computational Statistics. 14(2), 171-187.

Green, R. K. (2002). Stock prices and house prices in California: new evidence of a wealth effect? Regional Science and Urban Economics. 32(6), 775-784.

Guo, F., Hu, J., \& Jiang, M. (2013). Monetary shocks and asymmetric effects in an emerging stock market: The case of China. Economic Modelling. 32(0), 532-538.

Hafer, R. W., \& Sheehan, R. G. (1989). The sensitivity of VAR forecasts to alternative lag structures. International Journal of Forecasting. 5(3), 399-408.

Hall, S. G. (1989). PRACTITIONERS CORNER: Maximum Likelihood Estimation of Cointegration Vectors: An Example of The Johansen Procedureł. Oxford Bulletin of Economics and Statistics. 51(2), 213-218.

Hall, S. G. (1991). The Effect of Varying Length Var Models on the Maximum Likelihood Estimates of Cointegrating Vectors. Scottish Journal of Political Economy. 38(4), 317-323.

Hamdi, H., \& Sbia, R. (2013). Dynamic relationships between oil revenues, government spending and economic growth in an oildependent economy. Economic Modelling. 35, 118-125.

Hammoudeh, S., \& Choi, K. (2006). Behavior of GCC stock markets and impacts of US oil and financial markets. Research in International Business and Finance. 20(1), 22-44.

Han, A., Lai, K. K., Wang, S., \& Xu, S. (2012). An interval method for studying the relationship between the Australian dollar exchange rate and the gold price. Journal of Systems Science and Complexity. 25(1), 121-132.

Hillier, D., Draper, P., \& Faff, R. (2006). Do Precious Metals Shine? An Investment Perspective. Financial Analysts Journal. 62(2), 98106.

Holliday, K. (2013). Singapore Stocks at 2007 High, but Rally at Risk. Retrieved 10/12/2013, from http://www.cnbc.com/id/100698485

Hood, M., \& Malik, F. (2013). Is gold the best hedge and a safe haven under changing stock market volatility? Review of Financial Economics. 22(2), 47-52.

Hsu, K.-C., \& Chiang, H.-C. (2011). Nonlinear effects of monetary policy on stock returns in a smooth transition autoregressive model. The Quarterly Review of Economics and Finance. 51(4), 339-349.

Hui, E. C., \& Ng, I. M. (2012). Wealth effect, credit price effect, and the inter-relationships between Hong Kong's property market and stock market. Property Management. 30(3), 255-273.

Ibrahim, M. H. (2006). Integration or Segmentation of the Malaysian Equity Market: An Analysis of Pre- and Post-Capital Controls. Journal of the Asia Pacific Economy. 11(4), 424-443.

Jansen, D. W., Li, Q., Wang, Z., \& Yang, J. (2008). Fiscal policy and asset markets: A semiparametric analysis. Journal of Econometrics. 147(1), 141-150.

Jansen, D. W., \& Tsai, C.-L. (2010). Monetary policy and stock returns: Financing constraints and asymmetries in bull and bear markets. Journal of Empirical Finance. 17(5), 981-990.

Jiranyakul, K. (2011). Interaction between Stock and Foreign Exchange Markets Under the Floating Regime: Evidence from Thailand. Available at SSRN 1916549.

Johansen, S. (1992). Testing weak exogeneity and the order of cointegration in UK money demand data. Journal of Policy Modeling. 14(3), 313-334.

Joy, M. (2011). Gold and the US dollar: Hedge or haven? Finance Research Letters. 8(3), 120-131.

Kilian, L., \& Park, C. (2009). The Impact of Oil Price Shocks on The U.S. Stock Market. International Economic Review. 50(4), 12671287.

Kim, S., \& Roubini, N. (2000). Exchange rate anomalies in the industrial countries: a solution with a structural VAR approach. Journal of Monetary Economics. 45(3), 561-586. 
Kose, M. A., Hirata, H., Otrok, C., \& Terrones, M. (2012). Global House Price Fluctuations. NBER International Seminar on Macroeconomics 2012.

Laopodis, N. T. (2009). Fiscal policy and stock market efficiency: Evidence for the United States. The Quarterly Review of Economics and Finance. 49(2), 633-650.

Laopodis, N. T. (2013). Monetary policy and stock market dynamics across monetary regimes. Journal of International Money and Finance. 33(0), 381-406.

Le, T.-H., \& Chang, Y. (2011). Oil and gold: correlation or causation? MPRA Paper 31795. University Library of Munich, Germany.

Lee, B. S. (1992). Causal relations among stock returns, interest rates, real activity, and inflation. Journal of finance, 1591-1603.

Lee, C. C., \& Zeng, J. H. (2011). The impact of oil price shocks on stock market activities: Asymmetric effect with quantile regression. Mathematics and Computers in Simulation. 81(9), 1910-1920.

Li, Y., \& Wang, K. (1995). The predictability of REIT returns and market segmentation. Journal of Real Estate Research. 10(4), 471-482.

Liang, C.-C., Lin, J.-B., \& Hsu, H.-C. (2013). Reexamining the relationships between stock prices and exchange rates in ASEAN-5 using panel Granger causality approach. Economic Modelling. 32(0), 560-563.

Lin, T. C., \& Lin, Z.-H. (2011). Are stock and real estate markets integrated? An empirical study of six Asian economies. Pacific-Basin Finance Journal. 19(5), 571-585.

Ling, D. C., \& Naranjo, A. (1999). The integration of commercial real estate markets and stock markets. Real Estate Economics. 27(3), 483-515.

Linnemann, L., \& Schabert, A. (2004). Can fiscal spending stimulate private consumption? Economics Letters. 82(2), 173-179.

Liow, K. H. (2012). Co-movements and Correlations Across Asian Securitized Real Estate and Stock Markets. Real Estate Economics. 40(1), 97-129.

Liu, C. H., Hartzell, D. J., Greig, W., \& Grissom, T. V. (1990). The integration of the real estate market and the stock market: some preliminary evidence. The Journal of Real Estate Finance and Economics. 3(3), 261-282.

Lu, Y.-C., Chang, T., \& Wei, Y.-C. (2007). An Empirical Note on Testing the Co-integration Relationship between the Real Estate and Stock Markets in Taiwan. Economics Bulletin. 3(45), 1-11.

MAS. (2013). MAS Monetary Policy Statement. Retrieved 10/12/2013, from http://www.mas.gov.sg/news-and-publications/speechesand-monetary-policy-statements/2010/monetary-policy-statement-14apr10.aspx

Mensi, W., Beljid, M., Boubaker, A., \& Managi, S. (2013). Correlations and volatility spillovers across commodity and stock markets: Linking energies, food, and gold. Economic Modelling. 32(0), 15-22.

Mishkin, F. S. (2001). The transmission mechanism and the role of asset prices in monetary policy: National Bureau of Economic Researcho. Document Number)

Miyazaki, T., \& Hamori, S. (2013). Testing for causality between the gold return and stock market performance: evidence for 'gold investment in case of emergency'. Applied Financial Economics. 23(1), 27-40.

Mohanty, S., Nandha, M., \& Bota, G. (2010). Oil shocks and stock returns: The case of the Central and Eastern European (CEE) oil and gas sectors. Emerging Markets Review. 11(4), 358-372.

Mudakkar, R. S., \& Zaman, K. (Forthcoming). A wavelet analysis of oil prices and stock market: Evidence from Pakistan and India. Energy Policy.

Mulyadi, M. S., Anwar, Y., Khalid, K., Shawa, K. C., Singh, G., \& Ashraf, S. W. A. (2012). Gold versus stock investment: An econometric analysis. International Journal of Development and Sustainability

Narayan, P. K., Narayan, S., \& Prasad, A. (2008). Understanding the oil price-exchange rate nexus for the Fiji islands. Energy Economics. 30(5), 2686-2696.

Narayan, P. K., \& Sharma, S. S. (2011). New evidence on oil price and firm returns. Journal of Banking \& Finance. 35(12), 3253-3262.

Nawawi, A., Azmi, N. N. K., \& Fadzil, F. J. M. (2010). The Relationships of Real Estates and Stock Markets in Asia. Conference paper on 6th IMT-FT Conference on Mathematics, Statistics and its Applications.

Nneji, O., Brooks, C., \& Ward, C. W. R. (2013). House price dynamics and their reaction to macroeconomic changes. Economic Modelling. 32(0), 172-178.

Park, D., \& Estrada, G. E. B. (2011). Foreign exchange reserve accumulation in the ASEAN-4: challenges, opportunities, and policy options. Philippine Review of Economics. 47(1), 89-108.

Park, J., \& Ratti, R. A. (2008). Oil price shocks and stock markets in the U.S. and 13 European countries. Energy Economics. 30(5), 2587-2608.

Patelis, A. D. (1997). Stock Return Predictability and The Role of Monetary Policy. The Journal of Finance. 52(5), $1951-1972$.

Peltonen, T. A., Sousa, R. M., \& Vansteenkiste, I. S. (2012). Wealth effects in emerging market economies. International Review of Economics \& Finance. 24(0), 155-166.

Phylaktis, K., \& Ravazzolo, F. (2005). Stock market linkages in emerging markets: implications for international portfolio diversification. Journal of International Financial Markets, Institutions and Money. 15(2), 91-106.

Pirovano, M. (2012). Monetary policy and stock prices in small open economies: Empirical evidence for the new EU member states. Economic Systems. 36(3), 372-390.

Poon, W. C. (2010). Augmented MCi: AN Indicator Of Monetary Policy Stance For ASEAN-5? : Monash University, Department of Economicso. Document Number)

Reade, J. J. (2011). Modelling monetary and fiscal policy in the us: A cointegration approach. Discussion Papers, 11-02.

Reboredo, J. C. (2013). Is gold a hedge or safe haven against oil price movements? Resources Policy. 38(2), 130-137. 
Sellin, P. (2001). Monetary policy and the stock market: theory and empirical evidence. Journal of Economic Surveys. 15(4), $491-541$.

Soenen, L. A., \& Hennigar, E. S. (1988). An analysis of exchange rates and stock prices: The US experience between 1980 and 1986. Akron Business and Economic Review. 19(4), 7-16.

Solnik, B. (1987). Using Financial Prices to Test Exchange Rate Models: A Note. The journal of Finance. 42(1), 141-149.

Souček, M. (Forthcoming). Crude oil, equity and gold futures open interest co-movements. Energy Economics(0).

Tai, C.-S. (2007). Market integration and contagion: Evidence from Asian emerging stock and foreign exchange markets. Emerging Markets Review. 8(4), 264-283.

Thoma, M. (2008). Structural change and lag length in VAR models. Journal of Macroeconomics. 30(3), 965-976.

Thorbecke, W. (1997). On Stock Market Returns and Monetary Policy. The Journal of Finance. 52(2), 635-654.

Thuraisamy, K. S., Sharma, S. S., \& Ali Ahmed, H. J. (2013). The relationship between Asian equity and commodity futures markets. Journal of Asian Economics. 28, 67-75.

Tsai, I. C. (2012). The relationship between stock price index and exchange rate in Asian markets: A quantile regression approach. Journal of International Financial Markets, Institutions and Money. 22(3), 609-621.

Tsai, I. C. (2013). The asymmetric impacts of monetary policy on housing prices: A viewpoint of housing price rigidity. Economic Modelling. 31(0), 405-413.

Turhan, I., Hacihasanoglu, E., \& Soytas, U. (2013). Oil Prices and Emerging Market Exchange Rates. Emerging Markets Finance and Trade. 49, 21-36.

Wang, Y., Wu, C., \& Yang, L. (Forthcoming). Oil price shocks and stock market activities: Evidence from oil-importing and oil-exporting countries. Journal of Comparative Economics(0).

Wang, Y. S., \& Chueh, Y. L. (2013). Dynamic transmission effects between the interest rate, the US dollar, and gold and crude oil prices. Economic Modelling. 30(0), 792-798.

Wongbangpo, P., \& Sharma, S. C. (2002). Stock market and macroeconomic fundamental dynamic interactions: ASEAN-5 countries. Journal of Asian Economics. 13(1), 27-51.

World Factbook. (2013). Country Comparison to the World. Retrieved 10/12/2013, 2013, from https://www.cia.gov/library/ publications/the-world-factbook/fields/2186.html

Yao, S., Luo, D., \& Loh, L. (2012). On China's monetary policy and asset prices. Applied Financial Economics. 23(5), 377-392.

Zhang, Y.-J., \& Wei, Y.-M. (2010). The crude oil market and the gold market: Evidence for cointegration, causality and price discovery. Resources Policy. 35(3), 168-177. 